\title{
變諆陵の組菌に就いて（第1 報）
}

加藤 一 郎

(昭和 26 年 10 月 1 日受理)

\begin{abstract}
緒
言

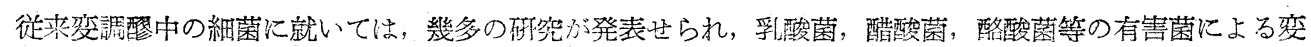
調を警告して扮られる。(1)(2)(3)

変調が或る種の細菌の增殖により起る事は明らかであるが，この細菌を導く原因や細菌の抗修作用に就い ては未だ明らかでない点があるようである。著者は変調型及びその㤌込用水卡り夫ふ球菌を分離し, 形態的 及艾生理的性筫を研究した結果両者同一の菌であることが判明したので第一報として報告する。
\end{abstract}

\section{实驗の部}

\section{1. 試料进びに菌の分離}

（イ）試料埼玉県下某酒浩場の蹘及び仕込用水（井戸水）(昭和 24 酒造年度）

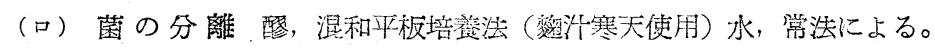

\section{2. 菌の形態的性啠}

（イ）形，大きさ 球型 2.5 3.5 $\mu$ 通常単独若くは策団的汇存在し 3 4 球連鎻状を呈する事るある。

(口) グラム染色 隄泩 (Hucker 方变法) (1)

(八) 運動性なし。

（二）胞子なし(石蓇上に分離試験) (5)

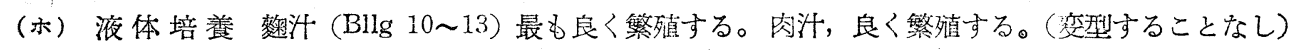
ペプトン水, 良く繁殖する(変型することなし)。

何れも恰も下面醭母の如く繁殖し液白体の溷濁なく液と硝子壁との境界線汇菌の聚落を生じ輪を作

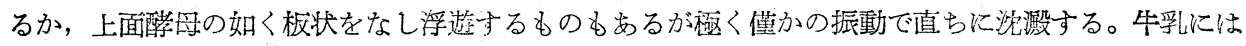
繁殖が少い。

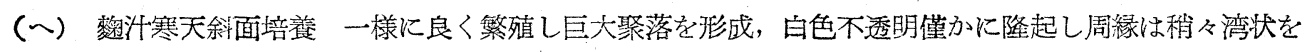
なし, 屙平でめる。

（ト）肉汁ゼラチン第刺培養 㖶線に沿いて繁殖するも主に表面によく繁殖する。

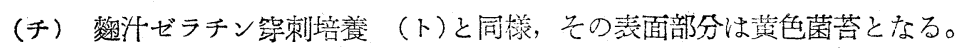

（リ）馬鈴著培養 繁殖良好, 白色素面に鳥跡状の裝を生ずる。

(ヌ)大豆絔エキス 良く繁殖する。

\section{3. 告理的性罂}

（イ）ゼラチン液化 - (口) カタラーゼ +（ハ）アンモニア生成 - (二) 硝酸塩還元 + （ホ）硫化水素生成 - （へ）アルコール生成 - （ト） ガス生産 - （チ）インドール生成 -

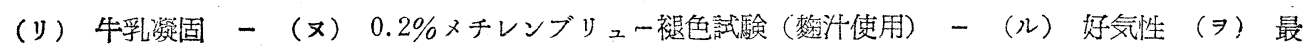

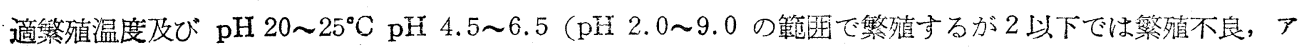

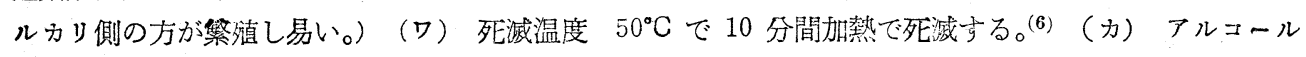

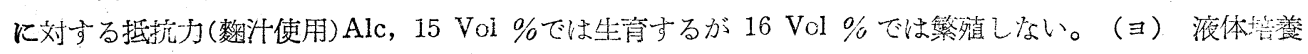

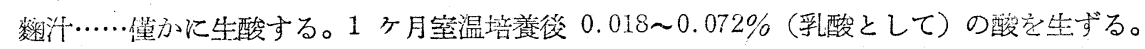

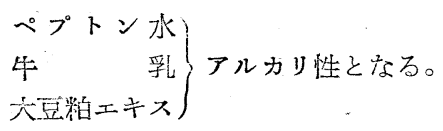

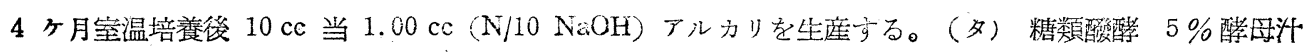




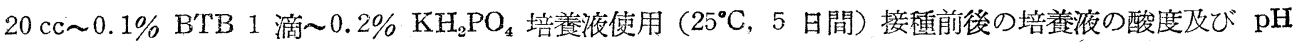

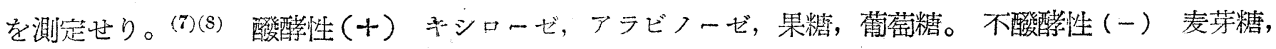

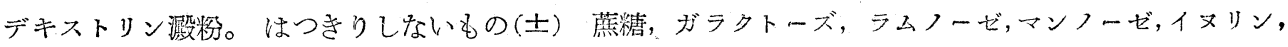
乳糖。

摘要：一ペプトンは武田栄養化学製ポリペプトン肉汁はミクニ化学産業製を使用。 $\mathrm{pH}$ は島津製 $3 \mathrm{P}$ 式,アンチモン電極伎用。

\section{4. 類 緣}

以上の一般的性質は小田雅夫氏が窝水より分離せる Micrococcus Sulfureus-magnus ODA に類似してい

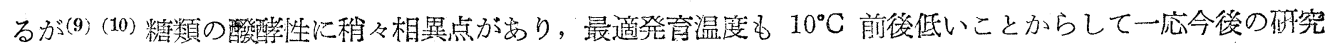
遂行上 Micrococcus sake Kato (M. S. K. 菌) と命名せり。

份 M. S. K. 菌と Asp. oryzae, Asp. Usamii, Penicillum Glaucum, Rasse No. 12, 清酒 7 号醭団 との抗啭作用汇関する碚究については第二報で行う。

\section{絡堒}

変調醪及び仕込用水より夫々球菌を分離しその形態的，生理的性質より両者同一の菌であることが判明し

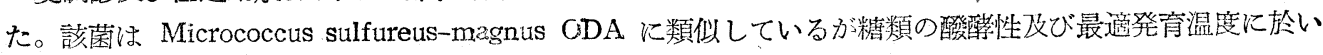
て相異点が見受けられるので M. S. I. 菌と命名せり。

本研究に当り種々御指導を瞈りたる当所長用中終太郎氏に樑謝いたします。

\section{引用文献}

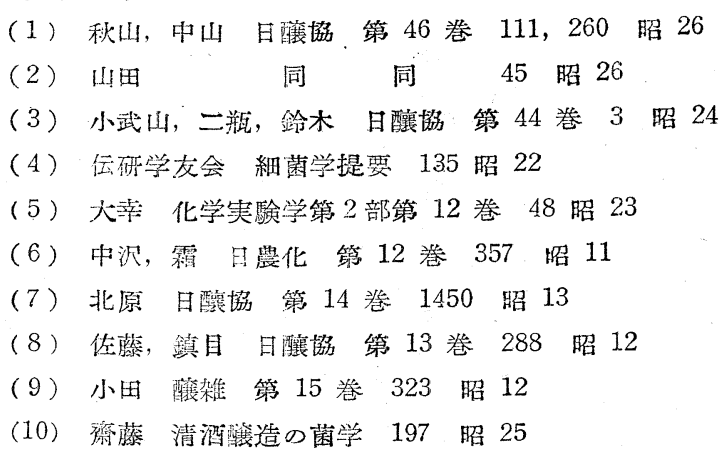

（埼玉具醸造指導所）

On the Bacteria of putrefied moromi-mash of sakè Part 1

By

Ichirō Katō

(Received Oct. 1, 1951)

\section{Summary}

The author isolated bacteria frỏm the putrefied moromi-mash of saké and its service-water from the well in Saitama-prefecture separately.

It was found that these two bacteria could be classified into the same species after the studies of morphological and physiological characters. It was very similar to Micrococcus sulf furesss-magnous CDA. and named Micrococcus sake KATO by reason of some different properties for the sugar fermentation and the most moderate temperature of cultivation. 